\title{
Cash Loans to Ottoman Timariots during Military Campaigns (Sixteenth-Seventeenth Centuries)
}

\section{A Vulnerable Fiscal System?}

\author{
Nil Tekgul \\ Bilkent University \\ niltekgul@yahoo.com
}

\begin{abstract}
Scholarship has argued that the Ottoman timar system was an efficient way to provide military forces in a non-monetized economy. As the state granted its sources of revenue to timariots in return for military service, it was financially relieved of the need to pay the expenses of the cavalry. Several documents so far neglected by scholars and evidencing the practice of cash loans to timariots during military campaigns prove otherwise. This paper analyzes the process of the generation of timariots' disposable income in the framework of actor-network theory. It is argued that the granting of loans demonstrated an attempt to regulate the cash flow of the timariot's income during campaigns, which was necessitated by problems of transforming tax revenues into disposable form. In the light of documents evidencing cash loans, it is further argued that cash loans reflect the vulnerability of the Ottoman timar system.
\end{abstract}

\section{Keywords}

Ottoman history - military history - timar - cash loans - actor-network theory

* This essay is a revised and expanded version of a paper that I presented at the 21st conference of CIEPO in Budapest held on 7-11 October 2014. I thank Özer Ergenç for his constructive criticism on earlier drafts of this paper. I also thank Evgenia Kermeli Ünal, Illker Aytürk and the three anonymous reviewers for JESHO for their insightful comments. Thanks are due also to Michael D. Sheridan and Alan Hartley for editorial support and copyediting. 
If, during the course of heady conversation and drinking, friends used cajolery to encourage [Hayali] to obtain a high state office and appraise him as having precedence over his peers, he would say, "If it's a worldly post [that you mean], the sound of its drum is a blinding headache, and command of it is a shackle on the feet."

AŞı ÇELEBI, Meşa'irü’ş-Şu'ara, Hayali-i Ma'ruf

Aşı Çelebi's words, cited in Stations of the Poets' Pilgrimage, reflect the famous sixteenth-century poet Hayali's (d. 1557) impression of revenue grants. For Hayali, grants were a shackle on the feet and the drum symbolizing the glory of the post was a blinding headache. The image of the ferocious sipahi (cavalryman) as depicted in Italian chronicles of the fifteenth century exercising his duty with the berat (warrant or appointment deed) of the sultan and the revenue grant in his pocket is a popular one. Why, then, would Hayali consider as a burden holding the prestigious official position of sancakbeyi (the highest administrator of a subprovince) in the Ottoman timar system? Indeed, some Ottoman primary documents concerning the payment of cash loans by the state to Ottoman timariots during the military campaigns, which have been neglected by historians so far, may provide us with insight into this question.

This paper has four main sections. The first is a brief review of our current knowledge of the Ottoman timar system, considering particularly its military features and its place in Ottoman state finance. The second explores the issue of cash loans made by the Ottoman state to timariots, drawing on evidence from chronicles, imperial decrees, records from mühimme defteri (registers of important affairs), and judicial court records. The third, inspired by John Law's actor-network theory (ANT), regards the Ottoman timar as a complex system of human and nonhuman heterogeneous actor networks. The last section analyzes the process of the generation of Ottoman timariots' disposable income in the context of heterogeneous networks as an attempt to explain possible factors necessitating the cash loans evidenced in section two. It is argued that the granting of loans reflects an attempt to regulate the cash flow of timariots'

1 Yaran 'alem-i sohbetde ve dem-i 'işretde ba'zı temvihat ile menasıb-ı 'aliyeye tergib eyleseler ve emsaline teşbihat ile mukaddemat-ı husulin tertib eyleseler eğer dünyanın sancağıdur hakikat-ı avaz-ı tablı kurı "baş ağrısıdır," serdarlığı "ayak bağı"dur dirdi. F. Kılıç, Aşık Çelebi, Meşa'irü’şŞu’ara, Inceleme-Metin (Istanbul: Istanbul Araştırmaları Enstitüsü Yayınları, 2010): 1545. Translation by Michael D. Sheridan. 
income during campaigns, necessitated by problems of transforming tax revenues into disposable form. In the light of documents evidencing cash loans from the early sixteenth century to the late seventeenth, it is further argued that timariots' need for cash reflects an inherent vulnerability in the system, independent of the sufficiency (or insufficiency) of tax allocations.

Major research on the Ottoman timar system began with seminal works by Halil Inalcık and Ömer Lütfü Barkan. ${ }^{2}$ Darling argues that, "in the midtwentieth century the timar was seen as the core issue in Ottoman history, the

2 See C. Üçok, "Osmanlı Devleti Teşkilatında Tımarlar." Ankara Üniversitesi Hukuk Fakültesi Dergisi 1/4 (1944): 525-51; M. Akdağ, "Tımar Rejiminin Bozuluşu." A ÜDTCF Dergisi 3/4 (1945): 419-31; H. Inalcık, "1431 Tarihli Timar Defterine Göre Fatih Devrinden Önce Timar Sistemi." In Osmanlı İmparatorluğu Toplum ve Ekonomi Üzerinde Arşiv Çalışmaları, İncelemeler (Istanbul: Eren: 1993): 109-14; id., "Osmanlılar'da Raiyyet Rüsumu." In Osmanlı Imparatorluğu Toplum ve Ekonomi: 31-66; id., "Köy, Köylü ve İmparatorluk.” In Osmanlı İmparatorluğu Toplum ve Ekonomi: 1-14; id., "The Çift-Hane System: The Organization of Ottoman Rural Society." In An Economic and Social History of the Ottoman Empire, 1300-160o, ed. H. Inalclk and D. Quataert (Cambridge: Cambridge University Press, 1994): 143-54; id., "Tımar." EI2 (Leiden: Brill, 2000): 502-507; id., "The Provincial Administration and the Timar System." In The Ottoman Empire, The Classical Age, 1300-1600, ed. Norman Itzkowitz and Colin Imber (London: Weidenfeld and Nicolson, 1973): 104-18; Ö.L. Barkan, "Feodal Düzen ve Osmanlı Tımarı." In Türkiye'de Toprak Meselesi: Toplu Eserler 1 (Istanbul: Gözlem, 1980): 873-95; id., “Tımar." In Türkiye'de Toprak Meselesi: Toplu Eserler 1: 805-72; M.A. Kılıçbay, Feodalite ve Klasik Dönem Osmanlı Üretim Tarzı (Ankara: Gazi Üniversitesi Yayınları, 1982); S. Divitçioğlu, Feodalite ve Klasik Dönem Osmanlı Üretim Tarzı (Istanbul: Teori, 1985); N. Beldiceanu, XIV. Yüzyıldan XVI. Yüzyıla Osmanlı Devletinde Timar, trans. Mehmet Ali Kılıçbay (Ankara: Teori, 1985); D. Howard, "The Ottoman Timar System and Its Transformation, 1563-1656." PhD diss. (Indiana University, 1987); C.C. Aktan, "Osmanlı Tımar Sisteminin Mali Yönü." Türk Dünyası Araştırmaları Dergisi 52 (1988): 69-78; H. İslamoğlu-İnan, State and Peasant in the Ottoman Empire: Agrarian Power Relations and Regional Economic Development in Ottoman Anatolia During the Sixteenth Century (Leiden: Brill, 1994); A. Singer, Palestinian Peasants and Ottoman Officials: Rural Administration around Sixteenth-Century Jerusalem (Cambridge: Cambridge University Press, 1994); H. Cin and G. Akylmaz, Tarihte Toplum ve Yönetim Tarzı Olarak Feodalite ve Osmanlı Düzeni (Konya: Selçuk Üniversitesi Yayınları, 1995); M.Öz, XV-XVI. Yüzyıllarda Canik Sancağı (Ankara: Türk Tarih Kurumu, 1999); B. Aydın, "XVI. Yüzyıl Osmanlı Bürokrasisinde Tımar Tevcih Sistemi." Osmanlı Araştırmaları Dergisi 24 (2004): 29-35; G. David and P. Fodor, "Changes in the Structure and Strength of the Timariot Army From the Early Sixteenth to the End of the Seventeenth Century." Eurasian Studies 4/2 (2005): 157-88; M. Soyudoğan, "Reassessing the Timar System: The Case Study of Vidin (1455-1693)." PhD diss. (Ankara: Bilkent University, 2012). 
characteristic institution of the empire's classical era; the device that united the military, the political, the economic and the social system; that made the empire successful, organized its resources, brought its people together, insured its prosperity, and created its identity."3 Although previous interest produced substantial scholarship on the subject, Darling rightly notes that interest has faded, in spite of numerous questions that remain unanswered. ${ }^{4}$

Considering the scope and content of this paper, "timar" may be defined as a military-administrative system in which the sultan granted the tax revenues of state-owned land to timariots in return for fulfilling certain military obligations. Ottomans themselves were more inclined to emphasize its military features. Earlier studies of the Ottoman timar system sought its roots in the older empires, especially the Seljukid and Byzantine, mainly because of the resemblances between Ottoman timar, the iqta ${ }^{5}$ of the Seljukids, and the pronoia of the Byzantines. ${ }^{6}$ Inalclk argued that the timar system was a common culture contributed to by ancient Persians, Byzantines, Western Europeans, the Islamic states, and Turco-Mongol states; it was apparently not unique to Ottomans. ${ }^{7}$ Their own practices developed under the influence of both preOttoman Turco-Islamic practices and the Byzantines.

It is possible to trace similarities between military-administrative systems not only across time in a particular geographical area but also across space during a given period. Similarities across space, in the vast geographical areas spanning from Western Europe to Far-East Asia, may be considered inevitable, given the production and transportation technologies available during the same period. In eastern Europe, for example, Muscovy's military apparatus consisted of a cavalry of provincial landholders who possessed landed estates (pomest'ia) apportioned to them by the grand prince. The pomest'e system, organized initially during the late fifteenth century, was a conditional form of land

3 L. Darling, "Nasihatnameler, İcmal Defterleri, and the Timar-Holding Ottoman Elite in the Late Sixteenth Century." Osmanlı Araştırmaları/The Journal of Ottoman Studies 43 (2014): 193.

4 Ibid.: 196. Although there are always unanswered questions in history, I believe her assertion rightly represents an implicit criticism of scholars in the field who suddenly put an end to institutional history studies and, without apology, developed a new tendency towards and interest in cultural-history studies.

5 For more on the iqta, see O. Turan, “Ikta." Islam Ansiklopedisi (Istanbul: Milli Eğitim Bakanlığı, 1993): 949-59.

6 While some scholars, such as Köprülü, Üçok, Cin and Akylmaz, Barkan, and Aktan emphasize the Seljuk antecedents of timar, others, such as Deny, Cahen, Vryonis, and Imber, suggest that the Ottoman timar was an adaptation of the Byzantine pronoia.

7 H. Inalcık, "Timar." EI2 (Leiden: Brill, 2000): 502. 
tenure in which the holders of pomest'a (pomeshchiki) were expected to appear fully armed with horses and provisions when summoned to a campaign. ${ }^{8}$

In a similar approach, basing their claims on resemblances and differences between the timar and Western European feudalism, Ottoman historians began in the 196os a hot debate on the question of Ottoman feudalism. ${ }^{9}$ Although several studies on the question expanded our understanding of timar as a socio-economic system, in the end, no consensus could be reached. This is not surprising, though, as feudalism was itself an abstraction constructed in the seventeenth century, mainly by legal scholars. ${ }^{10}$ However skeptical one may have been about the use of the term and however aware of the difficulties associated with defining the term, it remained a key concept for the study of the Middle Ages. ${ }^{11}$ Historians also compared societies in their search for similar

8 The Muscovite pomest'ia system is chosen as an example particularly because of its fiscal and military similarities to the Ottoman timar system during roughly the period under consideration. For more on the pomest'e system, see J. Martin, "Widows, Welfare, and the 'Pomest'e' System in the Sixteenth Century." Harvard Ukranian Studies 19 (1995): 375-88; id., "Economic Effectiveness of the Muscovite Pomest'e System: An Examination of Estate Incomes and Military Expenses in the Mid-16th Century." In Warfare in Eastern Europe, 1500-180o, ed. Brian Davies (Leiden: Brill, 2012): 19-34. For a comprehensive comparision between the Ottoman Empire and Russia regarding military fiscal and bureaucraticinstitutional transformation and the changing role of the central government between c.1500-c.180o, see G. Agoston, "Military Transformation in the Ottoman Empire and Russia, 1500-180o." Kritika: Explorations in Russian and Eurasian History 12/2 (2011):281-319. Some scholars, including Barkan and Cin and Akylmaz, claimed that Ottoman society could not be regarded as feudal because the actual ownership (rakaba) of the land was vested in the Ottoman state, and the timariot did not have jurisdictional rights. Marxist historians, including Divitçioğlu and Berktay, suggested, on the other hand, that Ottoman society had feudal characteristics; they positioned their analyses in the framework of either the feudal mode of production or Marx's Asiatic mode of production. Inalcık, however, offered the model of a "çift-hane system" as an alternative to the Marxist conception of "mode of production," in which the çift-hane represents the most basic unit of production, consisting of a family (hane), a pair of oxen (çift), and a piece of land (çiftlik). For more on the çifthane system, see H. Inalcık, “Osmanlılar'da Raiyyet Rüsumu.” In Osmanlı Imparatorluğu Toplum ve Ekonomi: 31-66; id., "The Çift-Hane System: The Organization of Ottoman Rural Society." In An Economic and Social History of the Ottoman Empire: 143-54.

10 Although many scholars were uncomfortable with the use of the term, the discomfort was first openly expressed by Brown (1974) and later developed by Reynolds (1994). See R. Abels, "The Historiography of a Construct: "Feudalism" and the Medieval Historian." History Compass 7/3 (2009): 1008-31.

11 For some of the major studies on feudalism, see M. Bloch, Feudal Society, vol. 1, trans. L.A. Manyon. (London: Routledge, 1978); F.L. Ganshof, Feudalism. trans. P. Grierson (New York: Harper and Row, 1964); F.M. Stenton, The First Century of English Feudalism 1066-1166 
"feudal" societies elsewhere. ${ }^{12}$ Discussions of Western or Ottoman feudalism or a comparative analysis of feudal societies elsewhere with timar system are not, however, within the scope of this paper, which is instead an attempt to understand the institution of the Ottoman timar and the relationships established within this system rather than questioning whether it was feudal or not, with occasional references made to similar military practices, if deemed necessary. ${ }^{13}$

Inalcık defines "timar," a word of Persian origin meaning literally "care, attention," as nonhereditary prebends used to sustain a cavalry and a militaryadministrative hierarchy in the core provinces of the Ottoman Empire and gives the Turkish equivalent of the term as dirlik, meaning "livelihood" or "means of support." ${ }^{14}$ In the timar system, the sultan granted tax revenues of a tract of state-owned (miri) land to members of the military class (askeri) in return for military and administrative services. Such grants of tax revenues ${ }^{15}$ were called timar, zeamet, or hass, depending on the amount of revenue they generated, timar being the smallest, granted to the common cavalryman. However, all grants, regardless of their size, were referred to generally in Ottoman documents as either timar or dirlik. The grantees were therefore referred to as dirlik owners, whether single cavalrymen, regimental commanders (alaybeyi), or provincial governors (beylerbeyi). The sultan was also a dirlik owner, of crown lands (padişah hassı). ${ }^{16}$ The main difference between timar holders (timariots) and zeamet or hass holders was that the rights to zeamet and hass grants was limited to the period of the owners' service. For example, the rights to the hass grants of any dismissed grand vizier were to be transferred to his replacement.

(Oxford: Oxford University Press, 1932); C. Stephenson, Mediaeval Feudalism (Ithaca NY: Cornell University Press, 1942); J.R. Strayer, Western Europe in the Middle Ages: A Short History (New York: Appleton-Century-Crofts, 1955).

For a comparative historical analysis of "feudalisms" in Russia, the Byzantine Empire, China, and Japan, see R. Coulborn, ed., Feudalism in History (Hamden CT: Archon Books, 1965). The scholars who contributed were, however, all aware of the problems with the use of the term "feudalism"; Strayer and Coulborn, in their introductory comments regarded comparative work as "an attempt to test the hypothesis that the methods of feudalism may have been applied, in whole or in part, outside Western Europe." J. Strayer and R. Coulborn, "The Idea of Feudalism": 3 .

13 Abels suggested that asking the question whether any society was feudal was less meaningful than understanding the institutions and relationships within that society in its historical context. R. Abels, “The Historiography of a Construct”: 1025.

14 H. Inalcık, "Tımar." EI2: 502.

15 Borrowing from medieval European history, Howard translated such grants as benefices. D. Howard, "The Ottoman Timar System and Its Transformation": 8.

16 Ö. Ergenç, XVI. Yüzyıl Sonlarında Bursa (Ankara: Türk Tarih Kurumu, 2014): 149. 
The rights of the timar-holding sipahi on the other hand were hereditary and could be passed from father to son under specified conditions, and the heir could not be dispossessed unless he violated the law. ${ }^{17}$

The tax income of the empire was divided into three in terms of the recipients: the sultan, the remaining dirlik owners (high state officials, zeamet owners, and timariots), and the evkaf (pious foundations, sing. vakf). Drawing his findings from the budget of the fiscal year 1527-28, Barkan showed that $49.8 \%$ of the total tax revenue of the empire was generated from the lands of dirlik owners, $39.9 \%$ from crown lands (the main source of income of the central treasury), and $10.3 \%$ from pious foundations. ${ }^{18}$ The tax income generated from $v a k f$ lands was spent for religious, health, educational, and other sorts of public service. ${ }^{19}$

The dirlik owners were obligated to join military campaigns in return for grants of tax revenue. They were also supposed to supply auxiliary men (cebelü) — using the income generated from their tax allocations-depending on the size of their dirliks. ${ }^{20}$ Most of the Ottoman army in the provinces during the classical period consisted of timariots. ${ }^{21}$ Research so far on Ottoman institutional history reiterates the argument that the timariots forming the cavalry did not need financial support from the state; rather, it was the salaried standing army that needed cash from central treasury, at least until the late seventeenth century, when dissolution of the system became apparent.

However, several documents - such as imperial decrees (ferman) and regulations regarding the repayment of cash loans made to the timariots during military campaigns which were conducted at various times and placeschallenge this assertion, as discussed in the next section.

17 H. Inalcık and D. Quataert, eds. 1994. An Economic and Social History of the Ottoman Empire: 115 .

18 The income generated from Egypt is not included in these numbers, but, if it is included in the total revenue of the empire, the income generated from crown lands increases to $51 \%$ and that from dirlik owners decreases to $37 \%$. Ö.L. Barkan, "Tımar." In Türkiye'de Toprak Meselesi: Toplu Eserler 1: 805-72.

19 H. Inalcık, "The Provincial Administration and the Timar System." In The Ottoman Empire: The Classical Age: 109.

20 Ibid.: 113.

21 For example, there were, in the year 1527-28, according to official Ottoman reports, 37,521 timar-holding sipahis, and the total number of soldiers in the army during this period is estimated at 70,000-80,000, including the cebelüs. Ö.L. Barkan. "Tımar." In Türkiye'de Toprak Meselesi: Toplu Eserler 1: 805-72. 
The following text from Tacü't-tevarih, an Ottoman chronicle, provides detailed information about the cash loans made to the timariots during the Çaldıran campaign of $1517:^{22}$

During the conquest of Egypt, besides the sultan's compensation in cash (bahşiş-i 'amm-ı padişahi), loans were made by the Imperial Treasury ${ }^{23}$ to Rumelian timariots who could not benefit from their own sources of income (dirliks), because their dirliks were far away and the routes of the campaign were long. Rumelian judges were entrusted with the task of organizing the repayment of loans-sometimes large — previously made to timariots. Imperial decrees (ferman) were issued on how the loans should be repaid and sent to the mentioned judges. It was ordered that the agents of dirlik owners should collect the tax payments on behalf of the timariots and that one judge from each subprovince should deliver the collected amount immediately to the Palace in Istanbul.

The first question that arises is whether or not this practice implemented in 1517 , when the timar as an institution was regarded as functional and efficient in maintaining an army, was exceptional: the recurring practice of making loans in the succeeding periods is evidence that it was not exceptional.

In a record ${ }^{24}$ from the mühimme register dated 1569 , the vizier, Mustafa Pasha, is ordered to make disbursements from the Aleppo treasury amounting

22 Şah-ı kişvergir azm-i teshir-i Mısr ittiğ̈̈ eyyamda Rumili sipahilerine bahşiş-i 'amm-ı padişahiden gayri tımarları dur ve bu'd-ı mekanla mahsullerinden intifa' gayr-i makdur olmağın, Hızane-i Amiremden karz vechi üzere herkese meblă̆-ı vafi verilmiş idi. Ve ol mebaliğ-i mevfure tahsili içün Rumili kadılarına ahkam-ı şerifde iblağ buyurulmuş idi ki istikraz iden sipahilerin tımarları mahsulatını vekilleri ve subaşıları marifetiyle cem`idüp, her sancakdan bir kadı livası mahsulunu ale't-ta'cil Bab-ı vacibit-tebcil savbına getüre. Hoca Saadettin Efendi, Tacüt Tevarih (Istanbul: Matbaa-i Amire, 1869): 2:377.

23 There were two imperial Ottoman treasuries, the internal treasury (Í $\dot{I}_{c}$ Hazine, called also Hazine-i Enderun and Hazine-i Hassa), controlled and managed by the sultan, and the external or central treasury (Dış Hazine, called also Miri Hazine, Divan-ı Hümayun Hazinesi, Hazine-i Birun, and Taşra Hazinesi), which was managed by the grand vizier and the head of financial administration. A. Tabakoğlu, "Osmanlı Devletinin İç Hazinesi." In Osmanlı Maliyesi Kurumlar ve Bütçeler ı, ed. M. Genç and E. Özvar (Istanbul: Osmanlı Bankası Arşiv ve Araştırma Merkezi, 2006): 51.

24 Vezirüm Mustafa Paşa'ya hüküm ki:... Buyurdum ki:... sipahi tayifesinden lazim oldukda, Haleb Hazinesinden ta'yin olunanyüz bin filoriden karz tarikryla olıgelen adet ü kanun üzre timarlarına göre tevzi idüp esamisiyle timar nahıyesin ve karyesin ve yazusın defter idüp 
to 100,000 flori as loans to timariots participating in the Yemen campaign and to see that each payment be properly recorded, including the amount, the name of the timar holder, and his village.

Similar cases appear in other Ottoman mühimme registers. In another record, ${ }^{25}$ from a mühimme register dated 1578 and addressed to Tirhala Beyi, he is ordered to disburse loans amounting to 45,00o kuruş to alaybegs, zeamet holders, and timariots who were participating in the eastern and the Sirvan campaigns and to take the utmost care in recording those payments in a register. It is further ordered that he should ensure that, if the timar grants were expropriated and transferred to someone else, they should be transferred together with their associated liabilities.

For example, imperial decrees ${ }^{26}$ were issued in 1639 to regulate the settlement of the loans made by the internal treasury to zaims (zeamet holders), and timariots during the army's return from the Baghdad campaign. The addressees of these decrees were the Rumeli beylerbeyi (governor of province), the sancakbeys (governor of sub-province) of İşkodra, Vulçitrin, Vidin, Selanik, Alacahisar, Dukakin, Prezrin, Üsküp, Elvine, Vize, Kırkkilise, Niğbolu and the judges in these sancaks. In other words, it included almost all of the officials in Rumeli Beylerbeyliği (province), depicting vividly the financial difficulties faced by the Rumelian timariots. It was ordered that the sum of the loans previously made by the internal treasury to zeamet and timar holders on their

üzerlerine ne mikdar altun virildüğin kaydeyleyesin. H.B. Ylldırım et al., eds. 7 Numaralı Mühimme Defteri (975-976/1567-1569), Özet-Transkripsiyon-İndeks (Ankara: Osmanlı Arşivi Daire Başkanlığı, 1999): 40.

25 Tirhala beğine hüküm ki: bundan akdem asakir-i mansureye serdar olan...vezirim Mustafa Paşa ... ile diyar-ı şarka ve Şirvan taraflarına seferde bile olup bi'l-fil kışlakda olan sancakların alaybeğilerine ve zü'ama ve erbab-ı timara karz tariki ile harçlık virilmek içün hızane-i amiremden kırk beş bin guruş ihrac eyleyüp... Tokat'da sana irsal olunmuşdur. Buyurdum ki, varup vusul buldukda Ohri beğine ve Avlonya beğilerine irsal olunan guruşdan ... kifayet mikdarı guruş virüp ... her birine ne mikdar akçe karz virildüğin defter eyleyüp... Amma hin-i tevzi' de zü'ama ve erbab-ı timarı ism ü resmleri ve ze'amet ve timarları ve karyelerin defter eylemekde ihtimam idesin. Sonra ze'amet ve timarları ahara virildüği takdirde karz virilen harçlık ze'amet ve timarlarından alınur ve ze'amet ve timarları ahara tevcih olundukda ol şartla tevcih oluna ve sancak beğlere ne mikdar harçlık virilürse anı dahi deftere kayd idesin. Ş. Izgi, "986 (1578) Tarihli 32 Numaralı Mühimme Defteri, [s. 201-40o], Transkripsiyonu ve Değerlendirmesi." Master's thesis (Istanbul: Marmara University, 2006): 101-102.

26 These twelve decrees are held in Topkapı Palace Archive (MS E.5207/1-12) and is described by I. Aydoğmuş, "Osmanlı Devletinde Timar Erbabına Hazineden Verilen Borçlar ve Geri Alınması: Sultan IV. Murat'ın Bağdat Seferi Örneği.” Paper presented at the 2oth CIÉPO Symposium, Rethymno: Crete, 2012.

JESHO 59 (2016) 590-617 
return from the Baghdad campaign be collected, placed in sealed sacks, and transported to Istanbul to be submitted to the internal treasury. ${ }^{27}$

Having established that loans were made to timariots poses another significant question - whether this practice was limited to the timariots of Rumelia. Apart from the decree of 1569 mentioned above, in which the origins of the timariots were not specified, the remaining examples used so far refer to Rumelian timariots participating in campaigns on the empire's far eastern front. However, there is one other record, dated January 1684 , that provides explicit evidence of loans made to Anatolian timariots (from the provinces of Anatolia, Sivas, Karaman, Adana, and Maraş). The evidence consists of a letter written by the kethüda (administrator) of the internal treasury to Sultan Mehmed IV, requesting disbursement from that treasury of 250,000 kuruş and the sultan's written consent for that payment. ${ }^{28}$

Although Tabakoğlu notes loans to timariots unable to collect taxes before campaigns, he concludes that it was a rare and unusual practice until late seventeenth century. ${ }^{29}$ Documents dated $1517,1569,1578$, 1639, and 1684 evidencing cash loans to Ottoman timariots during campaigns prove otherwise. It thus seems that state loans were frequently made even before the late seventeenth century. Even more striking, the decree dated 1569 in particular mentions the granting of these loans as appropriate according to law and custom (olugelen adet ve kanun üzere), which further supports the idea that it was not an unusual practice.

Are these documents sufficient to show that making cash loans to timariots on military campaigns was a usual practice? Can we find additional supporting evidence? Should we dismiss the documents, which date from the early sixteenth century to the late seventeenth century, even if they suggest a customary practice? Scholars may have neglected this practice because there was no series of registers of the disbursement and settlement of such loans.

27 Bundan akdem Bağdat seferinden avdet olundukda liva-i mezburun zǘama ve erbab-ı tımarına İç Hazine-i Amiremden karz tarikiyle virilen... guruşu cem've tahsil ve der-kise idüb, ve mühürleyüp ber vech-i ta'cil der saadete irsal ve İç Hazine-i Amireye teslim ettirmek. Topkapı Palace Archive Ms E.5207/8.

28 Request for disbursement: Anadolu'da vaki' mirimiran ve mirliva kullarına karz-ı şer'iden 100,00о kuruş ve zikrolunan sancaklarda miralay ve züama ve erbab-ı tımar ve defter olunduğu üzere 5,00o nefer olup birbirlerinin kefaletleri ile beher nefere зo kuruş bu cümle 250,00o kurus,, 500 kese olmak üzere Enderun-i hümayun hazinesinden ihsan buyurulur ise ferman devletlü ve saadetlü sultanım hazretlerinindir. Approval of Sultan Mehmed IV: "Hazine kethüdası karz olmak üzere 500 kese teslim edesin Defterdar Paşa'ya 3 m sene 96." İ.H. Uzunçarşıll, "Osmanlı Devleti Maliyesinin Kuruluşu ve Osmanlı Devleti İç Hazinesi." Belleten 42 (1978): 92.

29 A. Tabakoğlu, "Osmanlı Devletinin İç Hazinesi”: $5^{2}$. 
Unfortunately, it seems that the record-keeping system of the internal treasury was not as complex and sophisticated as that of the central treasury, thus making it more difficult to trace the transfers from the internal to the central treasury in detail, at least for the loans made to timariots. ${ }^{30}$ We do not yet have a full grasp of the procedures followed and the record-keeping practices of transactions of the internal treasury. Therefore, the scarcity of documents should not be deemed as insignificant. We may find only scattered information, especially on the issue of making cash loans to timariots. This is the main reason that several other primary documents-such as chronicles, important affair registers, judicial court records, and imperial decrees, rather than internal and central treasury registers - have been used as evidence in this paper. Instead of dismissing a number of documents evidencing cash loans to timariots, this paper attempts to explain the possible reasons behind such a necessity.

Scholars have so far relied mostly upon law codes (kanunname), survey registers (tahrir), and timar daybook-registers (ruznamçe defterleri) in their explorations of the Ottoman timar system. Such sources provide valuable insights into the theoretical design of this system. Although we know the amount of taxes granted to timariots in detail, we do not know whether they were collected in full. We do not know when the timariot could collect in full the tax in kind and store it in his warehouse or when he could take the grain to the nearest bazaar (akreb bazar) and actually convert tax in kind to cash for his disposable income. Moreover, we know nothing about the terms of his sale agreements with various buyers in the market. To this long list of lacunae we can add our ignorance as to whether the timariots could actually manage the effective collection of taxes in their absence during military campaigns. Despite our poor knowledge of such matters, there is no evidence of recurrent complaints that would lead one to question the adequacy of timar allocations,

30 In some of the primary sources, it is stated that the loans are made by the Hizane-i Amire (central treasury), while in others loans are made by the İç Hazine-i Amire (internal treasury). In still others, loans are made by the provincial treasuries (e.g., Aleppo). Usually, however, loans were made by the internal treasury, because the primary function of that treasury was to supplement the central treasury when necessary. The most comprehensive research regarding the Ottoman internal treasury has been done by Uzunçarşıll, "Osmanlı Devleti Maliyesinin Kuruluşu ve Osmanlı Devleti İç Hazinesi.” Belleten 42 (1978): 67-93. He explains that the internal treasury had several divisions and that the head treasurer (baş hazinedar) of the Inner Palace (Enderun) was the administrator of all the divisions. The records and registers of the internal treasury were kept by the Hazine Kethüdası, who reported directly to the sultan. He was also expected to keep the head accountant of the external treasury informed. 
at least until the late sixteenth century. ${ }^{31}$ The dissolution of the timar system in the seventeenth and eighteenth centuries was the result of many internal and external factors beginning in the late sixteenth century, such as evolving military technology ${ }^{32}$ and the devaluation of the currency leading to the erosion of the real value of timar revenues. ${ }^{33}$ This is consistent with the evidence of the use of credit in 1684, but the use of credit in 1517 , for example, seems to denote a different problem, independent of the sufficiency of tax revenues. John Law's actor-network theory might serve as an appropriate framework to explore further the possible need for cash loans.

\section{$3 \quad$ Human and Nonhuman Networks in the Timar System}

John Law, a sociologist and a key proponent of actor-network theory, presumes that "all social, organizational, scientific and technological structures,

31 Martin raised the problem of sufficiency in pomest'e system. She examined the expenses pomeshchiki incurred to meet their military obligations and compared them with their estate incomes to assess whether the pomeshchiki could afford financially their military service. A regulation issued in 1555-56 regarding Muscovy's military service required that each landholder supply additional armed men and horses, depending on the amount of productive land in his possession. She argued that, although the pomest'e system was functioning successfully in the mid-sixteenth century, the implementation of new regulations for military service and land tenure imposed a burden on pomeshchiki; for many of them, supplemental government stipends or salaries had become a necessary part of their incomes. J. Martin, “Economic Effectiveness of the Muscovite Pomest'e System”: 34. For Ottoman military power see: G. Agoston, "1453-1826 Avrupa'da Osmanlı Savaşları.” In Top, Tüfek ve Süngü. Yeniçağ'da Savaş Sanatı 1453-1815, trans. Yavuz Alagan (Istanbul: Kitap Yayınevi, 2003): 128-54; id., Guns for the Sultan Military Power and Weapons Industry in the Ottoman Empire (Cambridge: Cambridge University Press, 2005); id., "Military Transformation in the Ottoman Empire and Russia, 1500-180o." Kritika: Explorations in Russian and Eurasian History 12/2 (2011): 281-319; V. Aksan, "Ottoman War and Warfare 1453-1812." In War in the Early Modern World 1453-1815, ed. J. Black (London: University College, 1999): 147-75; id., Ottoman Wars 1700-1870: An Empire Besieged (Harlow UK: Pearson Educata, 2008); R. Murphey, Ottoman Warfare 1500-1700 (London: University College London Press, 1999); G. David and P. Fodor, "Changes in the Structure and Strength of the Timariot Army From the Early Sixteenth to the End of the Seventeenth Century." Eurasian Studies 4/2 (2005): 157-88; G. David, "Ottoman Armies and Warfare, 1453-1603." In Cambridge History of Turkey, vol. 2: The Ottoman Empire as a World Power, 1453-1603, ed. S. Faroqhi and K. Fleet (Cambridge: Cambridge University Press, 2013): 276-320.

33 On the erosion of the real value of timar allocations in the seventeenth and eighteenth centuries, see H. Inalcık, "Military and Fiscal Transformation in the Ottoman Empire, 1600-1700." Archivum Ottomanicum 6 (1980): 283-337. 
even processes and events, are formed from heterogeneous networks." Law's metaphor of heterogeneous networks, which lies at the heart of ANT, is a way of suggesting that society, organizations, agents, and machines are all effects generated in a patterned network of diverse (both human and nonhuman) materials. ${ }^{34}$ In this theory, materials, technology, and communication systems are also considered actor networks; this is what mainly differentiates it from the theory of social network analysis. ${ }^{35} \mathrm{He}$ further argues that "orders" (in its plural), be it a social order, an organization or a system, survive as long as they overcome resistance in these networks because any effort of ordering encounters its limits and struggles to overcome or accept those limits and thus liable to breakdown. ${ }^{36}$ His notion of heterogeneous networks is also applicable to the Ottoman timar system for a systematic analysis of the generation of the timariot's disposable income, because his theory considers not only several human networks established within the system but also the technology (production and communication) of the period as a constraint. Any flaw in actor networks remained as a threat to the well-functioning of the timar as a system. ${ }^{37}$ The key issue is to identify these actor networks.

\subsection{Human Networks}

The timar system served, above all, to define relations based on tax payments. The most fundamental network in this system was established between the state, the dirlik owner, and the tax-paying subjects (reaya). Although reaya denotes all tax-paying subjects, both the peasants as cultivators and urban producers, most of the reaya living on lands allocated to the timariots were peasants. The terms "peasant" and reaya are used interchangeably in this paper.

34 J. Law, "Notes on the Theory of the Actor Network: Ordering, Strategy and Heterogeneity." (Lancester: Centre for Science Studies, Lancaster University, 1992): 2-5. http://www.comp .lancs.ac.uk/sociology/papers/Law-Notes-on-ANT.pdf.

35 For a comparision of social-network analysis and actor-network theory, see T. Seçilmişler and Z. Yenen, "Koruma Sorunsalına İlişkin Kuramsal Bir Değerlendirme: Kurumsalcı (Alan Yönetimi) ve Çoğulcu (Aktör Ağ Teorisi) Yaklaşımlarının Karşılaştırılması.” Sigma 3 (2011): $375^{-84}$.

36 J. Law, "Notes on the Theory of the Actor Network": 5 .

37 Although the timar system as a whole included all the tax revenues granted to military members and even the sultan himself, this paper focuses only on the grant revenues of timariots. One of the reasons for this choice is their numerical predominance, but even more important is the fact that, because hass and zeamets were usually granted to high state officials, their income included not only the öşr tax, an agricultural tax collected in kind, but also some taxes collected in cash, such as the ihtisab or bac (market tax), and the gümrük (customs tax). The income of timariots was thus the lowest in absolute terms and the most vulnerable to resistances incurred during its collection. 
As stated previously, although the dirlik owner denotes every military class member possessing a tax revenue grant, including the sultan himself, the term refers in this article mainly to common timariots, unless otherwise specified.

In this complex relation based on tax, the state, the peasant and the dirlik owner were simultaneously exercising different rights to land. The title (rak$a b a)$ of land in this system belonged to the state, while the right to the usufruct (tasarruf) - that is, the cultivation and exploitation of land-belonged to the peasant who had, in return, an obligation to pay a portion of his income as tax to the dirlik owner. The dirlik owner, on the other hand, was entitled to tax revenues generated from the land cultivated by the peasant in return for administrative and military services. The income of the dirlik owner was derived only from the taxes explicitly defined in his berat, and the relationship between the timariot and the dirlik owner was clearly defined in the edicts of justice (adaletname).

One such edict, dated 1648 , shows the obligations of both parties, reflecting the theoretical model of the timar system. ${ }^{38}$ The edict states that the reaya should recognize his timariot as his master (ulu'l emr), a representative of the state, and show him respect and honor (ulu'l-emrbilüb, izzet ve hürmet itmekde). The reaya was expected to refrain from behaving obstinately or opposing his master (sözlerine inad ve muhalefet idüb). The reaya would pay the tithe (öşr) and other taxes in full and on time, without excuse. Any contrary act would be considered disobedience (ihtilaf) or rebellion (ihtilal). The reaya was also obligated to build a granary for his timariot to store the tithe, to transport the tithe to the nearest market (akreb bazar), and to place it wherever the dirlik owner demanded.

The timariot would, in return, provide protection to the reaya; this was his foremost obligation. ${ }^{39}$ The timariot thus acted as the representative of the state, and his rights and obligations were clearly specified in the berats issued by the sultan. ${ }^{40}$ The timariot did not have jurisdiction over the reaya $:{ }^{41}$ it was only the kadıs (judges) who had the right to adjudicate. In case of dispute, both the timariot and the reaya had the right to appeal to the judiciary court to

38 H. Inalcık, "Adaletnameler." In Osmanlida Devlet, Hukuk, Adalet (Istanbul: Eren, 2000): 169-70.

39 Ö. Ergenç, XVI. Yüzyıl Sonlarında Bursa: 136.

40 Ibid.: 146.

41 Some scholars, such as Cin and Akylmaz, have argued that the Ottoman timar was not "feudal," basing their claims on the timariots' lack of jurisdiction over peasants in the Ottoman case. H. Cin and G. Akyllmaz, Tarihte Toplum ve Yönetim Tarzı Olarak Feodalite ve Osmanlı Düzeni (Konya: Selçuk University, 1995). 
demand justice. Whether the system as prescribed in the law codes reflected practice remains to be answered.

When the dirlik owner joined a military campaign or was otherwise away from his dirlik, he could delegate his authority to his agent (vekil or subaşı). ${ }^{42}$ The legal owner of a right — defined in the warrants—could legally delegate his authority to one or more agents, a practice widespread in the Ottoman Empire. In such cases, the dirlik owner, as the legal owner of tax-collection rights, issued a letter to his delegate: the reaya would recognize the delegate's authority only upon the issuance of such a letter, and the relation between agent and peasant was one of the human networks in the system.

If the dirlik owner ran out of cash during a campaign, he usually appointed someone to deliver the already collected tax revenues in cash to one of the halting places on the army's campaign route. These agents were called harçlıkgı.. ${ }^{43}$ The network of relations formed between the dirlik owner and the harçlıķı was another human network in the timar system. Usually, dirlik owners from the same or nearby locations would appoint a common agent, making the system more affordable. During a long-distance military campaign, delivering cash might be dangerous. The success of the delivery depended on many factors, such as the nature of the tax to be collected, the timing of the tax collection, and even the trustworthiness of the harçlıkçı. Judicial records reflect the inevitable conflicts arising from this venture. A court record dated 5 April 1685 in the Konya court registers concerns the harçlıkçı of fifteen timariots from Konya who were on the Austrian campaign. ${ }^{44}$ In this record, Osman Ağa, the

42 Ö. Ergenç, “XVIII. Yüzyılda Osmanlı Taşra Yönetiminin Mali Nitelikleri.” In Osmanlı Tarihi Yazıları Şehir, Toplum, Devlet (Istanbul: Tarih Vakfi Yurt Yayınları, 2012): 369.

43 The harçlıkçı was a man delegated to collect the tax income generated from the dirliks of timariots when they were on military campaigns. M.A. Unal, Osmanlı Tarihi Sözlüğü (Istanbul: Paradigma, 2011): 295. For the only published work on the harçlıkçı, see G. Veinstein, "L'hivernage en campagne: Talon d'Achille du système militaire ottoman classique. A propos des Sipāhī de Roumélie en 1559-156o." Studia Islamica 58 (1983): 109-48. I am thankful to Amy Singer for bringing this article to my attention.

Mahmiye-i Konya sakinlerinden erbab-ı timardan hala Sefer-i hümayunda olan on beş neferin harclıkcısı olan.... Osman Ağa meclis-i şer'de Ahmed Ağa nam kimesnenin timarına subaşısı olan Hüdavirdi bin Ali mahzarında takrir-i kelam ve ta'bir-i 'ani'-meram idüb ben erbab-ı timar olub hala sefer-i hümayunda olan Ahmed Ağa tarafindan harclıkcı olub timarına mezkur Hüdavirdi subaşısı olmağla harclık taleb eylediğimde bana mezbur içün on guruş virüb ziyade taleb eylediğimde muhalefet ider sual olunub takriri tahrir olunması matlubumdur didikde gıbbe's-sual mezbur cevabında ben merkum Ahmed Ağa'nın subaşıs olub lakin aşar ve rüsumdan asla bir akçe ve bir habbe makbuzum olmamağla kendi malımdan on guruş tedarik idüb mezbur Ahmed Ağa'ya isal içün merkum Osman Ağa'ya virüb teslim eyledim bundan ziyade virmeğe iktidarım yokdur dimeğin ma-vak'a hafza li'lmakal bit-taleb ketb olundu fil-yevmi's-samin min Cemaziye'l- evvel li sene sitte ve tis'in ve 
delegated $h a r c ̧ l ı c ̧ \iota$ of these fifteen timariots, took to court the subaşı Hüdavirdi bin Ali, who was the appointed tax collector of the timariots. The harçlıkçı, as the plaintiff, declared that the subaşı paid him only ten guruş, although he had requested 15 guruş, and he demanded the remaining five guruş. However, the defendant, subaşı Hüdavirdi bin Ali, rejected the claim, stating that he had already paid ten guruş to the harçlıķı, adding that he made the payment from his own pocket, because the taxes had not yet been collected and he was financially unable to pay the balance. In this case, the tax collector clearly had to provide the stipulated tax amount before his collection was completed. The financial needs of the campaigning timariot are thus clearly indicated, alongside the risks taken by tax collectors.

The timariots usually sold the grain collected as tax in kind to the bakers ( $h a b b a z)$ in the nearest city or town. The relation between timariots and bakers (established in the process of converting tax in kind into cash as the timariot's disposable income) represents another human network in the system. Although we have little empirical information regarding the terms of the sales agreement between them, we can assume that these contracts were usually made on the basis of credit in a non-monetized economy.

The following example illustrates the difficulty faced in this process by the descendants of owners of timars and zeamets. In a case of inheritance dating to 1750, a woman named Ayşe claims her inheritance from the income of her deceased husband, a certain Ivaz Kethüda. Apparently, Ivaz Kethüda, a timariot, before his death made a tax-farming contract (iltizam) with two men collectively, Hasan Kethüda and El-Hac Mehmed. ${ }^{45}$ These two tax farmers sold on credit to people from the neighborhood and the city the grain they collected as tax in kind, but Ivaz Kethüda died before the actual date of payment. His wife Ayşe came into dispute with them when she requested her share from the tax farmers. The parties finally settled the dispute for 100 gurus. ${ }^{46}$

elf. M.A. Güven, “33 No'lu Konya Şeriyye Sicili Değerlendirme ve Transkripsiyon.” Master's thesis (Kayseri: Selçuk University, 2006): 289.

It was a widespread practice for the timariots to farm out their tax revenues, which is also evidenced by numerous fetvas (fatwas) issued on the disputes between timariots and mültezims (tax-farmer). For other examples, see K. Akpınar, "Iltizam in the Fetvas of Ottoman Şeyhülislams." Master's thesis (Ankara: Bilkent University, 2000): 42-58.

46 Medine-i Ankara hısn sakinlerinden iken bundan akdem vefat iden İvaz Kethüda... nam müteveffanın (varislerinin) vekili... Usulzade İbrahim Ağa meclis-i şer'de müteveffa-i mezburun hal-i hayatında ba'zı tımar ve ze'amet mahsulünü iltizamda şerikleri olan.... Hasan Kethüda...ve El-hac Mehmed... nam kimesneler mahzarlarında bi'l-vekale ikrar idüb, müvekkilem mezburenin zevci müteveffa-i mezbur Ivaz Kethüda hal-i hayatında şerikleri mezburan Hasan Kethüda ve El-hac Mehmed ile müşterekün fihi oldukları tımar ve ze'amet mahsulünden ma'lumü'l-aded ve'l-mikdar hinta ve şairi ahali-i kura ve mısrdan 


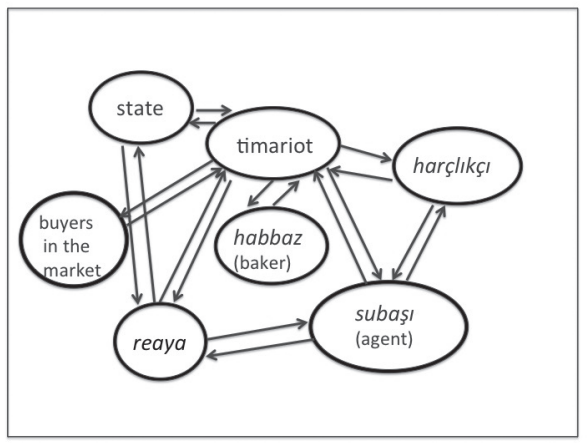

FIGURE 1 Human Networks.

The previous case makes it apparent that the relation between the timariot and the buyer on credit (zimem-i nas) is yet another actor network in the system. Deferred revenue of the timariot represents a flaw in the collection process of disposable income of the timariot and thus a threat to the wellfunctioning of the timar system. It seems that the tax collected in kind was not easily and quickly converted into cash. Although we do not know the terms of the original contract, the date of this record, 11 October, shows that the disposable income of the timariot had not yet been generated in full by mid-October.

Figure 1 illustrates several human networks in the timar system. Any flaw in any one of the actor networks subjects the system to the risk of dissolution. Indeed, court cases showing disputes within these actor networks are but a reflection of resistances to the system as a whole. The nonhuman networks are additional resistances to the system, as laid out in the next section.

\subsection{Nonhuman Networks}

Technology constitutes the nonhuman network in this system. Transportation technology based on human and animal power made it harder to reach the

ba'zı kimesnelere nüsheten kıymet-i malume ile bey ve teslim, anlar dahi ba'de'l-şıra ve'lkabul ale'l-esami ala haddihi defter olunub, her birileri ecel-i müsemma tamaminda tahsil ve kabza mütekarrib iken kabl-i hulu'l-u'l-ecl şerik-i mezbur İvaz Kethüda fevt olub, mahsul-i mezbur klymetinden zimem-i nasda olan sülüs hisse-i muayyenesini ber muceb-i defter-i müfredat şerikleri mezburan Hasan Kethüda ve El-hac Mehmed yedlerinden cem ve tahsil ve ahz ve kabz itmeleriyle sülüs-ı hisse-i mezkureden müvekkilem mezbure Ayşeye intikal ve isabet iden hisse-i ırsıyyesini makbuzları olmağla mezburan Hasan Kethüda ve El-hac Mehmed'den ahz murad ile taleb eylediğimde. Ankara Judicial Court Records 135:6. (Ottoman judicial court records are held in the National Library of Turkey, in Ankara, and are cited by volume and page number.) 
final destination of the military campaign (the battlefield) and required additional financial support. In other words, the distance of the battlefield from the dirlik was one of the main determinants of the system's success.

In addition to transportation technology, production technology and the mode of tax collection were important factors in the effective functioning of the system, because both the schedule and the mode of tax collection were functions of technology; this will be examined further in this section.

Ottoman revenues consisted of various taxes, duties, fees, and levies on production, trade, and the activities of daily life, and scholars have classified them in various ways. While some scholars have distinguished them as Islamic (şer $i$ ) taxes and sultanic (örfi) taxes, others have classified them according to their sources: tithes on agricultural and pastoral production, customs dues, and market taxes. ${ }^{47}$ Some scholars, such as Darling, have classified taxes according to the recipient of the income. ${ }^{48}$ Because my focus is on an analysis of the timariot's disposable income, it is logical to categorize taxes in three classes: the agricultural tithe (öşr), administrative taxes (niyabet rüsumu), and taxes of social status (raiyyet rüsumu). Exploring the collection schedule of these taxes will enable us to analyze better the cash flow of the timariot's income.

The öşr (lit., "one-tenth" in the original Arabic) tax (or tithe) - the rate of which varied depending on the productivity of land, irrigation conditions, type of agriculture, and the local traditions - usually constituted, according to Barkan, one-tenth of the agricultural produce. ${ }^{49}$ It was collected in kind at the end of the harvest season and could not be demanded earlier. The beginning of the harvest season was officially determined by the local kadıs; this was a widespread practice. For example, in a court record dated 29 May 1685, the local kadı set the official day of the harvest of barley (arpa) as 30 May. ${ }^{50}$

47 For a detailed description of taxes collected, see L. Fekete, “Türk Vergi Tahrirleri." Belleten 11/42 (1947): 299-328; N. Çağatay, "Osmanlı İmparatorluğunda Reayadan Alınan Vergi ve Resimler." AÜDTCFD 5 (1947): 483-511.

48 L. Darling, Revenue-Raising and Legitimacy: Tax Collection and Finance Administration in the Ottoman Empire, 1560-1660 (Leiden: Brill, 1996). She focuses on the group of taxes generated from crown lands (havas-ı hümayun), which entered the central government directly, before being spent.

49 The öşr tax varied significantly across the empire, for example, one-eighth of the produce in Kütahya and one-fifth or one-sixth in Diyarbakır. In Çirmek, the rate was set at onefifth for grain production, one-sixth for cotton, one-seventh for fruits, and one-tenth for vegetables. Ö.L. Barkan, "Öşür." In Türkiye'de Toprak Meselesi: 800-1.

50 Bi'l-fil mirmiran-ı Karaman olan... Rüstem Paşa hazretlerinin mütesellimi olan ... Mustafa A ̆̆a tarafindan... Mehmed Ağa ve Konya sancağında Aladă̆ kazasına tabi‘ Mahmudcalar nam karye sakinlerinden Mehmed ... ve diğer Mehmed ... nam kimesneler meclis-işer'de bir 
The relation between the peasant and the dirlik owner was founded mainly on trust expressed in oral agreements. On the other hand, the rights and obligations of the dirlik owner toward the state were written down and codified, thus limiting dirlik owners' flexibility in resolving disputes. Prolonged disputes with peasants affected directly the dirlik owners' obligations to the state. Registering the official harvest date in the court records was a way to reduce disputes over the collection of the öşr tax, but there were other reasons for such a registration. There were disputes regarding the legal owner of the taxes, in case the dirlik owner changed before the collection of taxes. In such cases, the official harvest time was the main determinant. The legal owner of the taxes was the one who held the grant at harvest time. A decree dated evahir-i Zilhicce 1061 (mid-December 1651), ${ }^{51}$ addressed to the kadıs of Ankara, Çukurcak, and other kadıs of the subprovince, relates a dispute regarding the collection of the öşr tax of lands in Haymana, the revenue of which was granted to Derviş Pasha. The agent (kethüda) of Derviş Pasha claims that the peasants had held payment of the öşr tax due because the revenue grant had been transferred to someone else. Apparently, the taxes had been allocated to another timariot after harvest. According to the court case, the owner of the right to collect taxes at the time of the harvest was the eventual recipient of them. It was ordered that the peasants were still obligated to pay the öşr tax to the agent of Derviş Pasha, who was the legal owner at the time of the harvest. Although the dirlik

deste arpa sünbülesi götürüb takrir-i kelam ve ta' bir-i 'ani'l-meram idüb Konya sancağında vaki' kaza ve mezra'da zira'at ve haraset olunan mahsulden ba'zıs yetişüb harman olmağa kabil olmuşdur yedimizde olan arpa sünbülesine nazar olunub vaki halin tahrir olunması matlubumdur didiklerinde ba'de'n-nazar arpa sünbülesi görülüb harman olunmağa kabil olduğu mütehhakkik olmağla Konya sancağının hasadı tarih-i kitab senesi Cemaziye’lahiresinin yimi altıncı günü olduğu müteayyin olmağın. Konya Judicial Court Records 33:8.

$5^{1} \quad$ Anadolu eyaletinde bundan akdem vezir-i müşarünileyhin üzerinde iken, mutasarrıf olduğu Haymana toprağını 1062 senesinde hasıl olan terekesi mahsulünün vakt-i hasadı tahviline düşüp lakin aşsar-ı şeriyyesi ahz ve kabz olunmayub, reaya üzerinde kalub, eyalet-i mezbure ahere verilmek ile, haliya reaya taifesi sene-i mezburede üzerlerinde kalan mahsulü virmekde taallül eylediklerin bildirüb, imdi, vakt-i hasadda tereke irişmeyüb, kemalin bulub, biçilmek kalil olan zamanda biçmek ve harman olunmak lazım değildir ol zaman vezir-i müşarünileyhin zamanında vaki olmuştur. Öşr-ü mahsül anın olur. Buyurdum ki,... sene-i mezburede terekenin vakt-i hasadıvezir-i müşarünileyhin zamanında olub, ve hass-ı mezbur toprağında hasıl olan terekenin öşrü alınmayub, reayanın zimmetlerinde baki kalmış ise, ol babda mukteza-i şer-i kavimle amel eyleyüb, reaya zimmetinde baki öşr-ü mahsulü vezir-i müşarünileyhin ademisine ahz ve kabz ittirüb, min bad şer'-i şerif ve emr-i hümayunuma mualif reaya taifesine bir vechile tallül ve inat ittirmeyesüz, amma mukayyed olasız, bu bahane ile reayadan bir senede iki defa mahsul alınmak ihtimali olmaya. Ankara Judicial Court Records 38:111. 
owner was, in this case, a pasha, a high state official, similar disputes were common among timariots as well.

The niyabet rüsumu was an administrative tax, part of which was demanded as compensation for the services rendered to reaya, such as the narh akçesi (fees charged for determining the prices of the goods sold), the pasban akçesi (service charge for the night watch), and the muhtesib akçesi (the cost of examining the weights and measures of goods sold). The period of collection was determined by the law codes. The narh akçesi, for example, was collected twice a year, in spring and fall. ${ }^{2}$ Most of the niyabet rüsumu, however, consisted of fines (cerime). Both the amount and the time of its collection could not be determined early; in other words, the schedule of the cash flow of the niyabet rüsumu was unpredictable. Thus, Ottoman finance officials termed this tax bad-i hava or tayyarat, meaning "coming from the air."

The raiyyet rüsumu also called çift resmi, was a social-status tax, the amount of which depended on the marital status of the peasant and the amount of land he cultivated. It was collected in cash. ${ }^{53}$ Inalckk argues that "Ottoman agrarian organization was based on the peasant family's labor (hane) and the yoked pair of oxen (çift), which together determined the size and production capacity of the land." ${ }^{54}$ The Ottoman çift-hane, corresponding to the Roman iugum-caput and the Byzantine statis or zugokefalai, as a production unit, formed a fiscal unit, consisting of a peasant family farm with two oxen and a defined amount of land; ${ }^{55}$ hence, according to Inalcık, the çift-hane system was the fundamental element of Ottoman agricultural production and rural society. The agrarian-fiscal system was represented by the çift resmi (peasantfamily tax).${ }^{56}$ Christians also paid the farm tax in cash, under the name ispence.

52 Ö. Ergenc, XVI. Yüzyıl Sonlarında Bursa: 158-63.

53 Çift-resmi was also called kulluk akçası, which, according to Inalcık, discloses its nature and origin. "Kulluk refers to the status of being a dependent, or a subject, or services owed as such. In this light, çift-resmi becomes the equivalent of the peasant's obligations to the landlord for kulluk or labor service. Fifteenth-century Ottoman law codes for example, record the 22, 12, 9, and 6 akça taxes as the cash equivalents of certain labor services ( $k u l-$ luk) such as personal service, providing a wagonload of hay, straw, firewood." H. Inalcık, "Osmanlılar'da Raiyyet Rüsumu." In Osmanlı İmparatorluğu Toplum ve Ekonomi: 31-66. For more on çift-resmi, see K. Orbay, "Osmanlı Çift-Hane Sistemi." Master's thesis (Ankara: Ankara University, 2011).

54 H. Inalcık, "The Çift-Hane System: The Organization of Ottoman Rural Society." In An Economic and Social History of the Ottoman Empire: 143.

55 Ibid.: 146.

56 The tütün resmi (hearth tax), the dönüm (land) tax, and other minor taxes also fell within this system of çift-hane. H. Inalcık, "The Çift-Hane System": 149. 


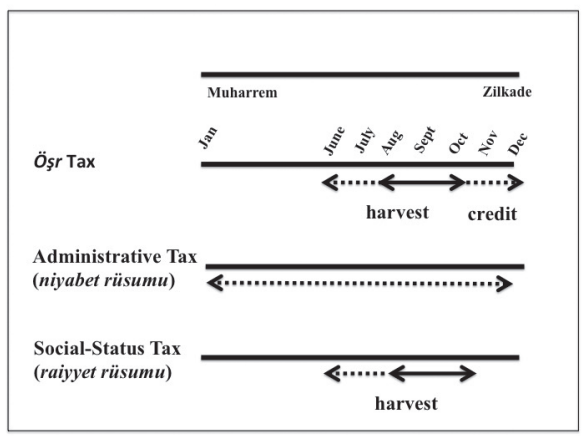

FIGURE 2 Schedule of Tax Collection.

Inalcık argues that the çift-resmi was usually collected after the harvest, and, according to most of the sixteenth-century law codes, the official date for its collection was set at 1 March. ${ }^{57}$ Although it was a tax that could be collected more easily, its share in the total amount of a timariot's tax income was small, for example, 22 akçe for a married peasant. ${ }^{58}$

Figure 2 summarizes the schedule for the collection of taxes classified as öşr, administrative tax, and social-status tax. The main source of income of a timariot on campaign was taxes collected in kind, and the schedule of their collection was an important determinant of his disposable income. The regular collection period of the taxes in kind was between August and October. It could, however, begin in June or even earlier, depending on the type of grain cultivated. If the tax in kind was collected by the end of October and transported to the warehouse of the timariot or the nearest market, it would still require additional time to convert it into cash. The share of the social-status tax in total income was, on the other hand, low compared to other taxes. The collection schedule of the administrative taxes could not be predicted or set in advance. Thus, it is clear that the bulk of the timariot's disposable income

57 H. Inalcık, "Osmanlılar'da Raiyyet Rüsumu." In Osmanlı Imparatorluğu Toplum ve Ekonomi: 41.

$5^{8}$ The fiscal system of çift-tax classified peasants as capable of paying the çift tax, the halfçift tax, the married peasant's (bennak) tax, or the poor or unmarried peasant's (mücerred, caba, or kara) tax. The amount of raiyyet rüsumu, although it long remained more or less stable, changed from place to place. For example, it was 30 akça for Aydın in 1455, 32 $a k c ̧ a$ for Kütahya in 1528 , and 37 akça for Ankara in 1522. For a complete list of these rates, see H. Inalcık, “Osmanlılar'da Raiyyet Rüsumu." In Osmanlı İmparatorluğu Toplum ve Ekonomi: 40. 
constituted of the ösr tax, and the nature and schedule of its collection were functions of the production technology. Technology in this system counted as a significant nonhuman network in addition to the previously cited human networks.

The Disposable Income Generation Process of an Ottoman Timariot

The military success of the Ottoman timar system, with the obligations of timariots to provide military troops in return for tax allocations, depended on accumulating enough cash for campaigns. Having previously identified the actor networks, Figure 3 analyzes the generation of the disposable income of a timar holder, helping us to understand the timariot's cash flow.

The first line of Figure 3 shows the schedule of the military campaigns during the classical period. The campaigns usually began in spring (nevruz) and ended in autumn. The timariots had to be back at their sources of revenue to collect their tax income, which required that campaigns ended by the end of August. Depending on specific conditions, the campaign might start earlier or last longer then expected.

As we have seen in the previous section, agrarian taxes constituted the main portion of the timariot's income. The second line in the figure shows the expected harvest period, ranging from June to October. Converting tax in kind to cash, however, demanded the sale of grain, usually on credit, which created further delays in producing disposable income of the timariot.

By comparing the campaigning schedule with that of tax collection, the third line demonstrates the cash flow of the timariot's income. At the beginning of the military campaign, the timariot's cash flow is positive, thanks to his accumulated income from the previous year's tax season. The cost of maintaining the timariot's family was another determinant of the cash accumulated from previous years. Although it is not within the scope of this article, the relations between the timariot and his family may be regarded as another actor network in the system. It seems clear, however, that the cash accumulated from the preceding year was insufficient to cover all his demands during the campaign. The cost of maintaining the cebelüs and their horses added to the financial burden. The widespread use of harçlıķı services is evidence of the desperate need for cash during campaigns. This demand required the timariot to hire a harçlıkç, who was expected to deliver either the already-collected tax or an advance on the expected tax revenue. The long process of converting tax in kind into cash and the length of time it takes for harçlıkçı to deliver cash to the battlefield 


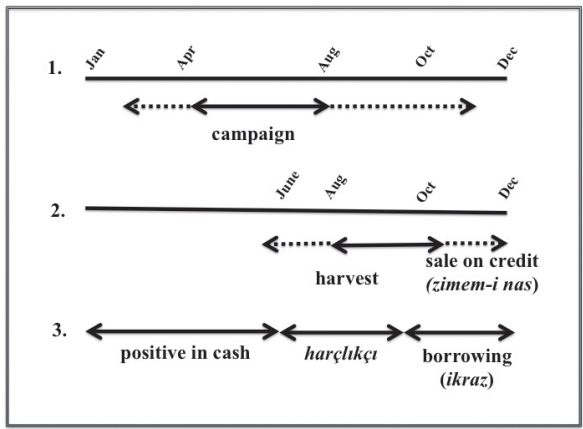

FIGURE 3 Campaign Season versus Disposable Income Generation Schedule.

both indicate additional problems in regulating cash flow during campaigns. During the return from campaigning, borrowing (karz tariki ile borç) from the state would be inevitable, as a last resort. The flaws within the networks during the collection period increased the support required to maintain cash flow. Cases of tax disputes, which constitute the majority of judicial court records, prove that timariots who were away from their income-generating sources during harvest periods needed additional financial support.

\section{Conclusion}

Several documents presented in this paper evidence the practice of making cash loans to Ottoman timariots during military campaigns from the early sixteenth to the late seventeenth century. The evidence proves that this was a regular practice, not an exception. Although it is clear that disbursements from the treasury were made as loans to timariots, it is not possible to precisely determine the extent of the state's success in their back payment from the sources available. Whether the loans were repaid or not, it is clear that it was not the salaried standing army only that demanded cash outlays from the Ottoman treasury; this refines our understanding of the place of the timar system in the Ottoman fiscal regime.

This paper has shown that the Ottoman timar, viewed as a complex system of heterogeneous actor networks, was a vulnerable system which necessitated the making of loans to help satisfy the timariots' need for cash as a remedy.

A part of the vulnerability was caused by the difficulties faced in the process of the generation of the timariot's disposable income. Taxes on agrarian production, which constituted most of the timariot's revenue, were collected 
at harvest time. More importantly, they could be transformed into disposable form only by the end of the year which did not perfectly match the campaigning schedule. This mismatch between the timing of harvest and campaign however was not the only cause of the timariot's dependence on cash support. It was also independent of the problem of the adequacy of timar allocations. Even if the revenues allocated were sufficient, the timing of cash generation from tax revenues usually prevented the timariots from covering their expenditures during campaigns.

There were also resistances within the human networks that needed to be resolved for the system to function efficiently. Any flaw in the relations of the timariot with his agent delegated to collect taxes in his absence, with the peasants, with the bakers in the market, and with his harçlıkçı, each representing a different human-actor network, was a threat to the system's success.

The Ottoman timar system seems to have overcome various resistances within actor networks, as reflected in its success during the classical period. Scholars have so far demonstrated several reasons for its success. The measures taken as a remedy to the vulnerability of the system, evidenced in this paper, consisted of the practice of hiring harçıkçıs to regulate their cash flow and cash loans made to timariots during campaigns to facilitate financial problems of the timariots. The practice of making loans to timariots was apparently an indication of a long-term compromise and negotiation between the state and the timariots. When considering holding a dirlik as "a shackle on the feet" and "a blinding headache," the famous Ottoman poet Hayali was perhaps implicitly reflecting some of the strains in several heterogeneous networks in the timar system.

\section{Abbreviations}

$\begin{array}{ll}\text { ANT } & \text { actor-network theory } \\ \text { AÜDTCF } & \text { Ankara Üniversitesi Dil Tarih Coğrafya Fakültesi } \\ \text { EI } & \text { Encyclopaedia of Islam }\end{array}$

\section{Bibliography}

Abels, Richard. 2009. The Historiography of a Construct: "Feudalism" and the Medieval Historian. History Compass 7/3: 1008-31.

Acun, Fatma. 2002. Klasik Dönem Eyalet İdare Tarzı Olarak Tımar Sitemi ve Uygulaması.

In Türkler, ed. Hasan Celal Güzel, Kemal Çiçek, and Salim Koca. Ankara: Yeni Türkiye Yayınları: 6: 899-908. 
Agoston, Gabor. 2003. 1453-1826 Avrupa'da Osmanlı Savaşları. In Top, Tüfek ve Süngü. Yeniçağ'da Savaş Sanatı 1453-1815. Trans. Yavuz Alagan. Istanbul: Kitap Yayınevi: 128-54.

2005. Guns for the Sultan: Military Power and Weapons Industry in the Ottoman Empire. Cambridge: Cambridge University Press.

- 2011. Military Transformation in the Ottoman Empire and Russia, 1500-1800. Kritika: Explorations in Russian and Eurasian History 12/2: 281-319.

Akdağ, Mustafa. 1945. Tımar Rejiminin Bozuluşu. AÜDTCF Dergisi 3/4: 419-31.

Akpınar, Kürşat. 2000. İltizam in the Fetvas of Ottoman Şeyhülislams. Master's thesis. Ankara: Bilkent University.

Aksan, Virginia. 1999. Ottoman War and Warfare 1453-1812. In War in the Early Modern World 1453-1815, ed. Jeremy Black. London: University College: 147-75.

-2008. Ottoman Wars 1700-1870: An Empire Besieged. Harlow U K: Pearson Educata. Aktan, Coşkun Can. 1988. Osmanlı Tımar Sisteminin Mali Yönü. Türk Dünyası Araştırmaları Dergisi 52: 69-78.

Aydın, Bilgin. 2004. XVI. Yüzyıl Osmanlı Bürokrasisinde Tımar Tevcih Sistemi. Osmanlı Araştırmaları Dergisi 24: 29-35.

Aydoğmuş, Ismail. 2012. Osmanlı Devletinde Timar Erbabına Hazineden Verilen Borçlar ve Geri Alınması: Sultan IV. Murat'ın Bağdat Seferi Örneği. Paper presented at the 2oth CIÉPo Symposium, Rethymno, Crete.

Barkan, Ömer Lütfü. 1980. Feodal Düzen ve Osmanlı Tımarı. In Türkiye'de Toprak Meselesi: Toplu Eserler 1. Istanbul: Gözlem: 873-95. . 1980. Öşür. In Türkiye'de Toprak Meselesi: Toplu Eserler 1. Istanbul: Gözlem: 799-804.

—. 1980. Tımar. In Türkiye'de Toprak Meselesi: Toplu Eserler 1. Istanbul: Gözlem: $805^{-72}$.

Beldiceanu, Nicoara. 1985. XIV. Yüzyıldan XVI. Yüzyıla Osmanlı Devletinde Tımar. Trans. Mehmet Ali Kılıçbay. Ankara: Teori.

Berktay, Halil. 1983. Kabileden Feodalizme. Istanbul: Kaynak Yayınları.

- 1992. The Search for the Peasant in Western and Turkish History/Historiography. In New Approaches to State and Peasant in Ottoman History, ed. Halil Berktay and Suraiya Faroqhi. London: Frank Cass: 211-42.

Black, Jeremy, ed. 2003. Top, Tüfek ve Süngü. Yeniçağ'da Savaş Sanatı 1453-1815. Trans. Yavuz Alagan. Istanbul: Kitap Yayınevi.

Bloch, Marc. [1961] 1978. Feudal Society. Vol. 1. Trans. L.A. Manyon. London: Routledge. Brown, Elizabeth A.R. 1974. The Tyranny of a Construct: Feudalism and Historians of Medieval Europe. The American Historical Review 79/4: 1063-88.

Çağatay, Neşet. 1947. Osmanlı İmparatorluğunda Reayadan Alınan Vergi ve Resimler. A ÜDTCF Dergisi 5: 483-511.

Chaen, Claude. 1956. Selçuki Devletleri Feodal Devletler Mi İdi? Istanbul Üniversitesi Íktisat Fakültesi Mecmuası 17/1-4: 348-58. 
Cin, Halil, and Gül Akyılmaz. 1995. Tarihte Toplum ve Yönetim Tarzı Olarak Feodalite ve Osmanlı Düzeni. Konya: Selçuk Üniversitesi Yayınları.

Coulborn, Rushton, ed. 1965. Feudalism in History. Hamden cт: Archon Books.

Darling, Linda. 1996. Revenue-Raising and Legitimacy: Tax Collection and Finance Administration in the Ottoman Empire, 1560-166o. Leiden: Brill.

- 2014. Nasihatnameler, İcmal Defterleri, and the Timar-Holding Ottoman Elite in the Late Sixteenth Century. Osmanlı Araştırmaları/The Journal of Ottoman Studies 43: 193-226.

David, Geza. 2013. Ottoman Armies and Warfare, 1453-1603. In Cambridge History of Turkey. Vol. 2: The Ottoman Empire as a World Power, 1453-1603, ed. Suraiya Faroqhi and Kate Fleet. Cambridge: Cambridge University Press: 276-320.

David, Geza, and Pal Fodor. 2005. Changes in the Structure and Strength of the Timariot Army From the Early Sixteenth to the End of the Seventeenth Century. Eurasian Studies 4/2: 157-88.

Deny, Jean. 1936. Timar. $E I$. Leiden: Brill: 767-76.

Divitçioğlu, Sencer. 1985. Feodalite ve Klasik Dönem Osmanlı Üretim Tarzı. Istanbul: Teori.

Duus, Peter. 1993. Feudalism in Japan. New York: McGraw-Hill.

Ergenç, Özer. 1995. Osmanlı Klasik Dönemi Kent Tarihçiliğine Katkı XVI. Yüzyılda Ankara ve Konya. Ankara: Ankara Enstitüsü Vakfı Yayınları.

—. 2014 [2006]. XVI. Yüzyıl Sonlarında Bursa. Ankara: Türk Tarih Kurumu.

—. 2012 [1986]. XVıIı. Yüzyılda Osmanlı Taşra Yönetiminin Mali Nitelikleri. In Osmanlı Tarihi Yazıları Şehir, Toplum, Devlet. Istanbul: Tarih Vakfı Yurt Yayınları: $367-82$.

Fekete, Lajos. 1947. Türk Vergi Tahrirleri. Belleten 11/42: 299-328.

Ganshof, F.L. 1964. Feudalism. Trans. P. Grierson. New York: Harper and Row.

Güven, Mehmet Ali. 2006. 33 No'lu Konya Şeriyye Sicili Değerlendirme ve Transkripsiyon. Master's thesis. Kayseri: Selçuk University.

Hammond, Vincent E. 2009. State Service in Sixteenth Century Novgorod: The First Century of the Pomestie System. Lanham MD and Plymouth U K: University Press of America.

Hoca Saadettin Efendi. 1869. Tacü't Tevarih. Vol 2. Istanbul: Matbaa-i Amire.

Howard, Douglas. 1987. The Ottoman Timar System and Its Transformation, 1563-1656. $\mathrm{PhD}$ diss. Bloomington: Indiana University.

Imber, Colin. 2002. The Ottoman Empire, 1300-1650: The Structure of Power. New York: Palgrave Macmillan.

Inalcık, Halil. 1973. The Provincial Administration and the Timar System. In The Ottoman Empire, The Classical Age, 1300-1600, ed. Norman Itzkowitz and Colin Imber. London: Weidenfeld and Nicolson: 104-18.

1980. Military and Fiscal Transformation in the Ottoman Empire, 1600-1700. Archivum Ottomanicum 6: 283-337. 
1993 [1952]. 1431 Tarihli Timar Defterine Göre Fatih Devrinden Önce Timar

Sistemi. In Osmanlı İmparatorluğu Toplum ve Ekonomi Üzerinde Arşiv Çalışmaları, Incelemeler. Istanbul: Eren: 109-14.

- 1993 [1950]. İslam Arazi ve Vergi Sisteminin Teşekkülü ve Osmanlı Devrindeki

Şekillerle Mukayesesi. In Osmanlı İmparatorluğu Toplum ve Ekonomi Üzerinde Arşiv Çalısmaları, Incelemeler. Istanbul: Eren: 15-30.

—_ 1993 [1990]. Köy, Köylü ve İmparatorluk. In Osmanlı İmparatorluğu Toplum ve Ekonomi Üzerinde Arşiv Çalışmaları, İncelemeler. Istanbul: Eren: 1-14.

—_ 1993 [1959]. Osmanlılar'da Raiyyet Rüsumu. In Osmanlı İmparatorluğu Toplum ve Ekonomi Üzerinde Arşiv Çalışmaları, İncelemeler. Istanbul: Eren: 31-66.

- 1994. The Çift-Hane System: The Organization of Ottoman Rural Society. In An

Economic and Social History of the Ottoman Empire, 1300-160o, ed. Halil Inalcık and

Donald Quataert. Cambridge: Cambridge University Press: 143-54.

—. 2000 [1965]. Adaletnameler. In Osmanlida Devlet, Hukuk, Adalet. Istanbul:

Eren: 75-190.

— 2000. "Timar." In EI2. Leiden: Brill: 502-07.

Inalcık, Halil, and Donald Quataert, ed. 1994. An Economic and Social History of the

Ottoman Empire, 1300-1600. Cambridge: Cambridge University Press.

İslamoğlu-İnan, Huri. 1994. State and Peasant in the Ottoman Empire: Agrarian Power

Relations and Regional Economic Development in Ottoman Anatolia During the

Sixteenth Century. Leiden: Brill.

Izgi, Şuayib. 2006. 986 (1578) tarihli 32 Numaralı Mühimme Defteri, [s. 201-40o],

Transkripsiyonu ve Değerlendirmesi. Master's thesis. Istanbul: Marmara University.

Kantorowicz, Ernst H. 1965. Feudalism in the Byzantine Empire. In Feudalism in

History, ed. Rushton Coulborn. Hamden c т: Archon Books: 151-67.

Kılıç, Filiz, ed. 2010. Aşık Çelebi, Meşairü'ş-Şu'ara, İnceleme-Metin. Istanbul: Istanbul Araştırmaları Enstitüsü Yayınları.

Kılıçbay, Mehmet Ali. 1982. Feodalite ve Klasik Dönem Osmanlı Üretim Tarzı. Ankara: Gazi Üniversitesi Yayınları.

Köprülü, Mehmet Fuat. 2004 [1931]. Bizans Müesseselerinin Osmanlı Müesseselerine Tesiri. Ankara: Akçă̆.

Law, John. 1992. Notes on the Theory of the Actor Network: Ordering, Strategy and Heterogeneity. Lancester: Centre for Science Studies, Lancaster University. http:// www.comp.lancs.ac.uk/sociology/papers/Law-Notes-on-ANT.pdf.

Martin, Janet. 1995. Widows, Welfare, and the "Pomest'e" System in the Sixteenth Century. Harvard Ukranian Studies 19: 375-88.

- 2012. Economic Effectiveness of the Muscovite Pomest'e System: An Examination of Estate Incomes and Military Expenses in the Mid-16th Century. In Warfare in Eastern Europe, 1500-180o, ed. Brian Davies. Leiden: Brill: 19-34. 
Murphey, Rhoads. 1999. Ottoman Warfare 1500-1700. (London: University College London Press)

Orbay, Kayhan. 2011. Osmanlı Çift-Hane Sistemi. Master's thesis. Ankara: Ankara University.

Öz, Mehmet. 1999. XV-XVI. Yüzyıllarda Canik Sancağı. Ankara: Türk Tarih Kurumu.

Reynolds, Susan. 1994. Fiefs and Vassals: The Medieval Evidence Reinterpreted. New York and Oxford: Oxford University Press.

Seçilmişler, Töre, and Zekiye Yenen. 2011. Koruma Sorunsalına İlişkin Kuramsal Bir Değerlendirme: Kurumsalcı (Alan Yönetimi) ve Çoğulcu (Aktör A ̆ Teorisi) Yaklaşımlarının Karşılaştırılması. Sigma 3: 375-84.

Singer, Amy. 1994. Palestinian Peasants and Ottoman Officials: Rural Administration around Sixteenth-Century Jerusalem. Cambridge: Cambridge University Press.

Soyudoğan, Muhsin. 2012. Reassessing the Timar System: The Case Study of Vidin (1455-1693). PhD diss. Ankara: Bilkent University.

Stenton, Frank M. 1932. The First Century of English Feudalism 1066-1166. Oxford: Oxford University Press.

Stephenson, Carl. 1942. Mediaeval Feudalism. Ithaca NY: Cornell University Press.

Strayer, Joseph R. 1955. Western Europe in Middle Ages: A Short History. New York: Appleton-Century-Crofts.

Strayer, Joseph, and Ruston Coulborn. 1965. The Idea of Feudalism. In Feudalism in History, ed. Rushton Coulborn. Hamden C T: Archon Books: 3-11.

Tabakoğlu, Ahmet. 2006. Osmanlı Devletinin İç Hazinesi. In Osmanlı Maliyesi Kurumlar ve Bütçeler 1, ed. Mehmet Genç and Erol Özvar. Istanbul: Osmanlı Bankası Arşiv ve Araştırma Merkezi.

Turan, Osman. 1993. İkta. Islam Ansiklopedisi. Istanbul: Milli Eğitim Bakanlığı: 949-59.

Üçok, Coşkun. 1944. Osmanlı Devleti Teşkilatında Tımarlar. Ankara Üniversitesi Hukuk Fakültesi Dergisi 1/4: 525-51.

Ünal, Mehmet Ali. 2011. Osmanlı Tarihi Sözlüğü. Istanbul: Paradigma.

Uzunçarşılı, İsmail Hakkı. 1978. Osmanlı Devleti Maliyesinin Kuruluşu ve Osmanlı Devleti İç Hazinesi. Belleten 42: 67-93.

Veinstein, Gilles. 1983. L'hivernage en campagne: Talon d'Achille du système militaire ottoman classique. A propos des Sipāhī de Roumélie en 1559-156o. Studia Islamica 58: $109-48$.

Vryonis, Speros, Jr. 1971. The Decline of Medieval Hellenism in Asia Minor and the Process of Islamization from the Eleventh through the Fifteenth Century. Berkeley and London: University of California Press.

Yıldırım, Hacı Bayram, et al., eds. 1999. 7 Numaralı Mühimme Defteri (975-976/15671569): Özet-Transkripsiyon-İndeks. Ankara: Osmanlı Arşivi Daire Başkanlığı. 